Article

\title{
Phytotoxic Compounds Isolated from Leaves of the Invasive Weed Xanthium spinosum
}

\author{
Zhuogeng Yuan ${ }^{1,+}{ }^{\dagger}$ Xiangwei Zheng ${ }^{2,+}$, Yu Zhao ${ }^{3}$, Ying Liu ${ }^{3}$, Shixing Zhou ${ }^{4}$, Caixia Wei ${ }^{4}$, \\ Yunxia $\mathrm{Hu}^{1, *}$ and Hua Shao ${ }^{4, *}$ \\ 1 Chemistry and Environment Science School, Yili Normal University, Yining 835000, China; \\ yzg821871139@outlook.com \\ 2 Engineering Research Center of Modern Preparation Technology of TCM, Ministry of Education, \\ Shanghai University of Traditional Chinese Medicine, Shanghai 201203, China; zhengxwsh@hotmail.com \\ 3 Bioscience and Geosciences School, Yili Normal University, Yining 835000, China; \\ 2001zhaoyu@sohu.com (Y.Z.); zylyzhlily@126.com (Y.L.) \\ 4 Key Laboratory of Biogeography and Bioresource in Arid Land, Xinjiang Institute of Ecology and \\ Geography, Chinese Academy of Sciences, Urumqi 830011, China; zhoushixing16@mails.ucas.ac.cn (S.Z.); \\ weicaixia16@mails.ucas.ac.cn (C.W.) \\ * $\quad$ Correspondence: yunxiahu1214@163.com (Y.H.); shaohua@ms.xjb.ac.cn (H.S.); Tel.: +86-991-7823-155 (H.S.) \\ + These authors contributed equally to this work.
}

Received: 1 October 2018; Accepted: 28 October 2018; Published: 1 November 2018

check for updates

\begin{abstract}
The aim of this study was to identify bioactive compounds from leaves of the invasive plant Xanthium spinosum and assess their phytotoxic activity. Activity-guided fractionation led to the isolation of 6 bioactive compounds: xanthatin (1), $1 \alpha, 5 \alpha$-epoxyxanthatin (2), 4-epiisoxanthanol (3), 4-epixanthanol (4), loliolide (5) and dehydrovomifoliol (6). Of them, compounds 2-6 were isolated from the X. spinosum for the first time. The structures of 1-6 were elucidated on the basis of extensive NMR studies and ESI-MS measurements as well as comparison with literature data. All of compounds were evaluated for their phytotoxic activity. Among them, compounds 1-4 exhibited stronger activity on 2 receiver plants compared with the other 2 compounds, with xanthatin (1) being the most potent compound, which suppressed root growth of the dicot plant Amaranthus retroflexus by $32.5 \%, 39.4 \%, 84.7 \%$ when treated xanthatin (1) at 5, 20, and $100 \mu \mathrm{g} / \mathrm{mL}$, while for the monocot plant, root growth was inhibited by $14.7 \%, 28.0 \%$, and $40.0 \%$, respectively. Seedling growth was nearly completely inhibited when the concentration of xanthanolides increased to $500 \mu \mathrm{g} / \mathrm{mL}$, whereas there was still some seedling growth when loliolide (5) and dehydrovomifoliol (6) were applied at the same concentration. Dehydrovomifoliol (6) did not negatively affect seedling growth of P. annua at all tested concentrations, and root length was still $42.0 \%$ of the control when the highest concentration $500 \mu \mathrm{g} / \mathrm{mL}$ was used. This is the first report of the phytotoxicity of $1 \alpha, 5 \alpha$-epoxyxanthatin (2), 4-epiisxanthanol (3) and 4-epixanthanol (4). These compounds have the potential to be utilized as natural herbicides, especially 4-epiisoxanthanol (3), which exhibited significant selective activity between the dicot and monocot plants. On the other hand, whether these bioactive substances serve as allelochemicals to facilitate the invasion success of X. spinosum needs to be further studied.
\end{abstract}

Keywords: phytotoxicity; allelopathy; bioactive compounds; natural herbicide; Xanthium spinosum

\section{Introduction}

Exotic plant invasion poses serious threat to the conservation of ecosystems due to its negative impacts on local plant community by displacing native plant species or inhibiting the establishment of new individuals [1]. Exotic plants are often found to perform better in their invaded ranges than in their native ranges, and a number of hypothesis have been proposed attempting to elucidate the 
mechanism causing this phenomenon, including enemy release, enhanced mutualist, novel weapons, accumulation of local pathogens, etc. [2-4]. Among them, the "novel weapons hypothesis" suggests that allelopathy may play an important role in the invasion process of exotic plants via the production of novel allelochemicals, which presumably possess potent phytotoxic effect on native species due to the lack of coevolution [4-6]. Allelopathy refers to any direct and indirect harmful or beneficial effect by one plant on another through the production of chemical compounds that release into the nearby environment [7]. There have been a number of reports on the possible involvement of allelopathy in the invasion success of some exotics; however, the "novel weapons hypothesis" has been challenged ever since it was proposed due to the complicated mechanism of allelopathy [8-11].

China is one of the countries that suffer severe consequences caused by biological invasions. Lots of invasive species belong to the Asteraceae family, possibly due to their ability of producing a variety of secondary metabolites with various biological activities [12]. Among the Asteraceae plants, Xanthium spinosum L., commonly known as spiny cocklebur, is an herbaceous annual weed in the genus Xanthium which includes 25 species that originates from South America and now distributes in nearly all parts of the world [13]. X. spinosum was first discovered in Henan province, China in 1981, and then gradually spreads to other provinces such as Liaoning, Xinjiang, Anhui, Gansu, Ningxia, Inner Mongolia in the past decades [14-17]. The spiny fruits of X. spinosum not only cause wool fault problems, as they can contaminate the fleeces of grazing sheep, but is also considered an effective biological characteristic that facilitates this plant's quick spread [18].

According to the "novel weapons hypothesis", the exotic X. spinosum might release some naive substances into the environment that native species are more sensitive to. It is believed that allelochemicals produced by exotic plants might either directly accumulate in the soil at effective doses to affect neighboring plants' growth, or by indirectly alter soil properties including community structure of soil microorganisms, physical and chemical characteristics, and so on [19,20]. Our previous investigation revealed that the ethanol extracts of leaves, stems, roots, and fruits of X. spinosum all exhibited phytotoxic activity at different levels against receiver plants, with leaf extract being the most potent [21]. Combined with the fact that the leaves represent relatively the largest amount of biomass compared to other plant parts (i.e., stems, roots and fruits) of X. spinosum, we selected leaves for further isolation of phytotoxic compounds.

\section{Results and Discussion}

\subsection{Isolation and Identification of Six Phytotoxic Compounds}

Column chromatography and semi-preparative HPLC of ethyl acetate extract of leaves of X. spinosum led to the isolation of 6 compounds. The compounds were identified as xanthatin (1) [22], $1 \alpha, 5 \alpha$-epoxyxanthatin (2) [23], 4-epiisoxanthanol (3) [22], 4-epixanthanol (4) [22], loliolide (5) [24], and dehydrovomifoliol (6) [25], by alignment with spectral data reported in the literature (Figure 1). Of them, compounds 2-6 were isolated from the X. spinosum for the first time. 


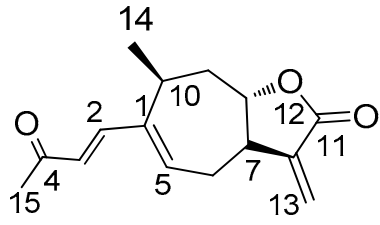

1. xanthatin

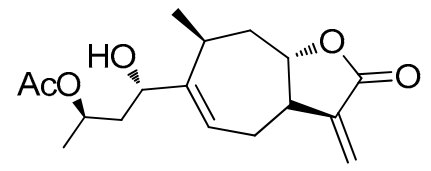

3. 4-epiisoxanthanol

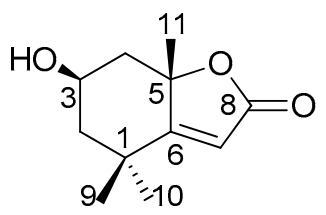

5. loliolide<smiles>C=C1C(=O)O[C@H]2C[C@H](C)[C@]3(/C=C/C(C)=O)O[C@H]3CC12</smiles>

2. $1 \alpha, 5 \alpha$-epoxyxanthatin

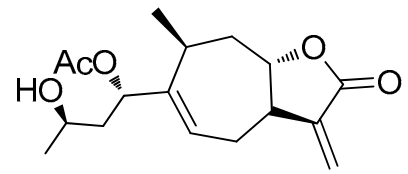

4. 4-epixanthanol

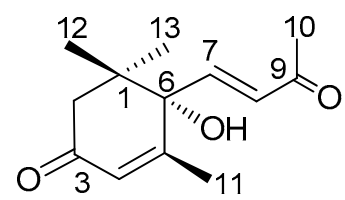

6. dehydrovomifoliol

Figure 1. Chemical structures of 1-6.

\subsection{Phytotoxic Effect of Isolated Compounds}

In general, compounds 1, 3 and $\mathbf{4}$ exhibited stronger inhibitory effect on the monocot plant, P. annua, compared with compound 2, which showed more potent effect on the dicot plant, A. retroflexus. Among the six compounds, compound 1 possessed the strongest inhibitory activity against $A$. retroflexus with an $\mathrm{IC}_{50}$ of $28 \mu \mathrm{g} / \mathrm{mL}$ for its root growth; meanwhile, compound 3 showed the most potent activity against $P$. annua with an $\mathrm{IC}_{50}$ of $56.8 \mu \mathrm{g} / \mathrm{mL}$ for root growth. Starting from a very low concentration $(5 \mu \mathrm{g} / \mathrm{mL})$, root growth of $A$. retroflexus was significantly inhibited by $32.5 \%$ and $16.7 \%$ when treated with compounds $\mathbf{1}$ and $\mathbf{2}$, whereas root growth of $A$. retroflexus was significantly increased by $23.9 \%$ and $37.2 \%$ when treated with compounds 5 and $\mathbf{6}$; meanwhile, root growth of $A$. retroflexus was not significantly affected either by compound 3 or $\mathbf{4}$ at the same concentration. When the concentration was increased to $20 \mu \mathrm{g} / \mathrm{mL}$, root growth of $A$. retroflexus was significantly inhibited by $39.4 \%, 31.0 \%$ and $17.7 \%$, respectively, when treated with compounds $\mathbf{1}, \mathbf{2}$ and $\mathbf{4}$; however, it was not significantly affected by compounds 3,5 and $\mathbf{6}$ at such concentration. When the concentration reached $100 \mu \mathrm{g} / \mathrm{mL}$, root growth of $A$. retroflexus was significantly suppressed by $84.7 \%, 62.1 \%, 54.6 \%$ and $36.9 \%$, respectively, when compounds $1-4$ were applied, with compound 1 possessing the strongest activity. At the highest concentration tested $(500 \mu \mathrm{g} / \mathrm{mL})$, seed germination of A. retroflexus was mostly completely inhibited by compounds $\mathbf{1 - 4}$ (Figures 2 and 3). Their phytotoxic effect was similar on shoot growth of receiver plants but at a lesser extent (Figures 4 and 5). 


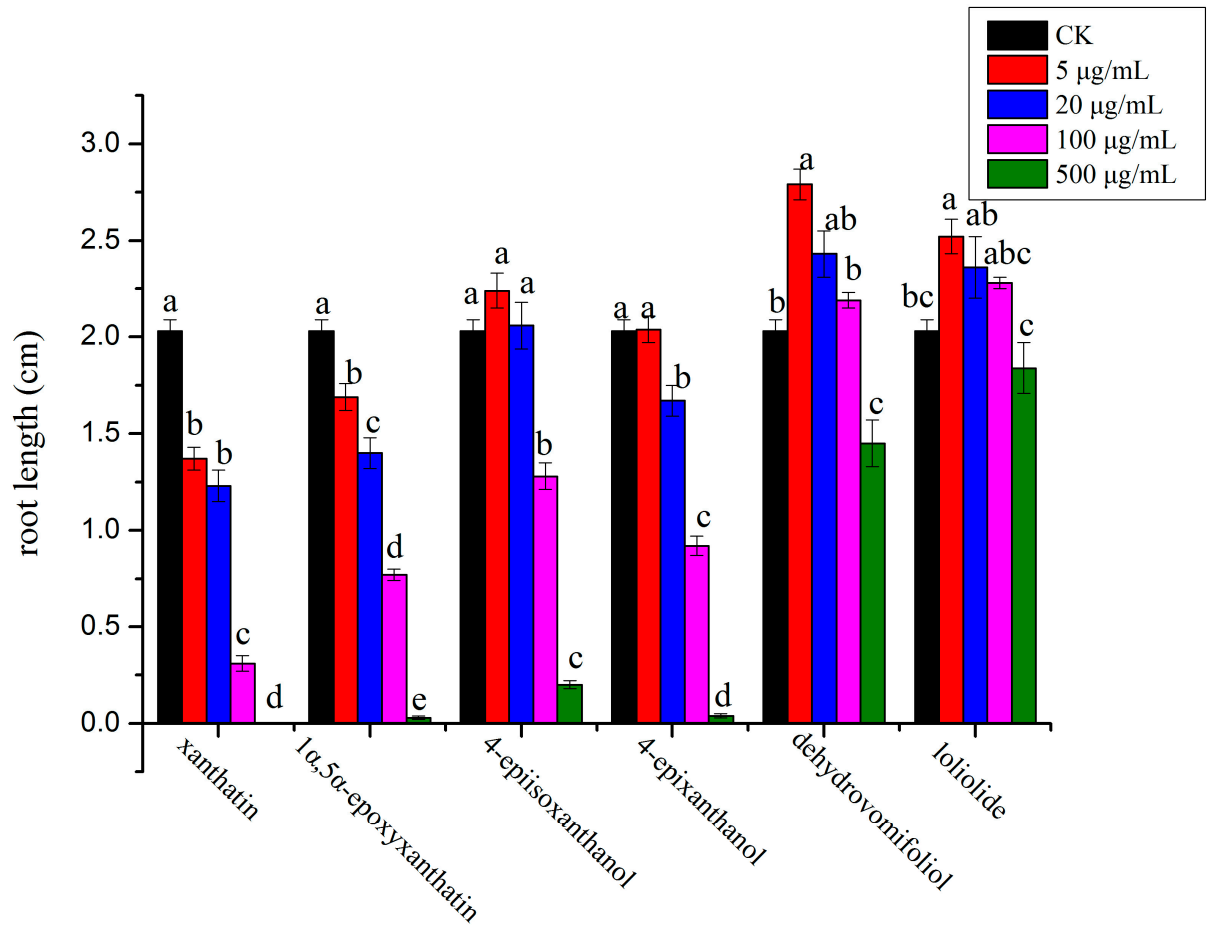

Figure 2. Phytotoxic effect of isolated compounds on root growth of A. retroflexus. Different letters represent a significant difference at $p<0.05$ level according to Fisher's LSD test.

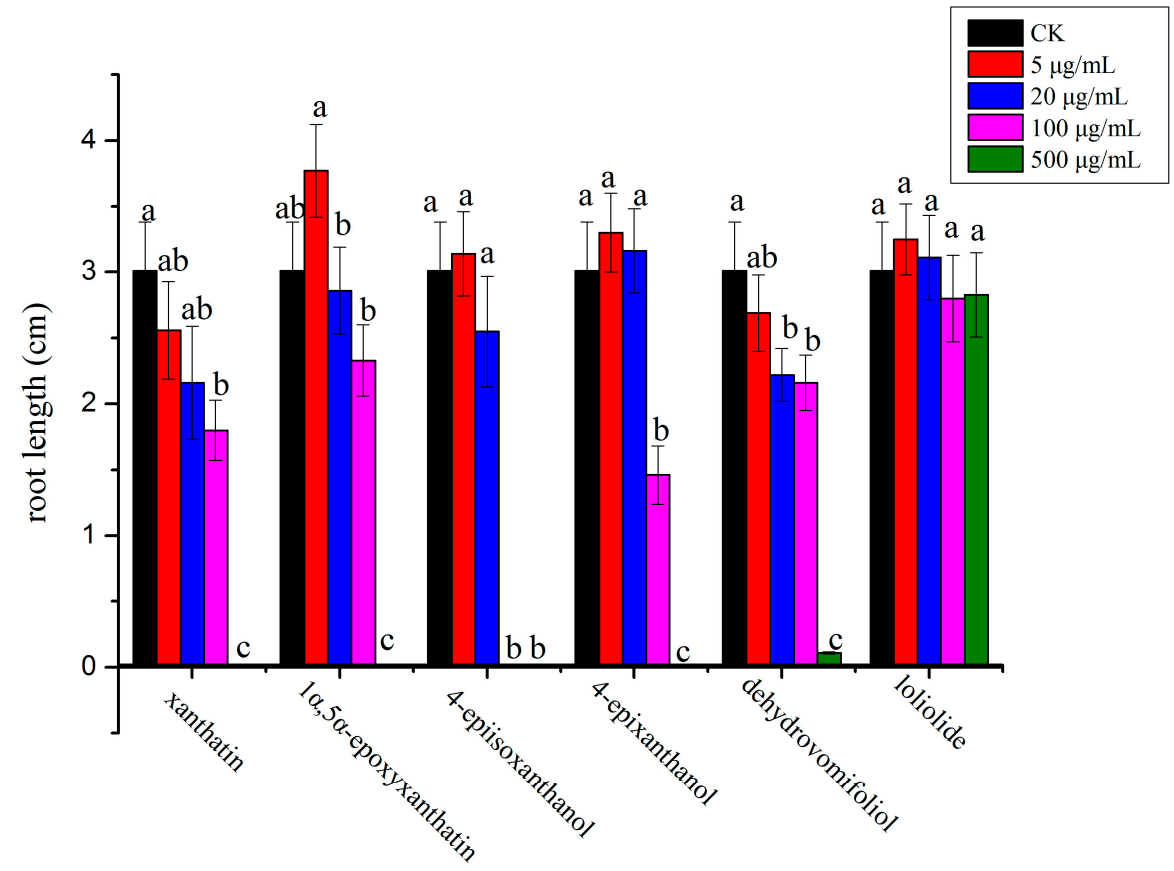

Figure 3. Phytotoxic effect of isolated compounds on root growth of P. annua. Different letters represent a significant difference at $p<0.05$ level according to Fisher's LSD test. 


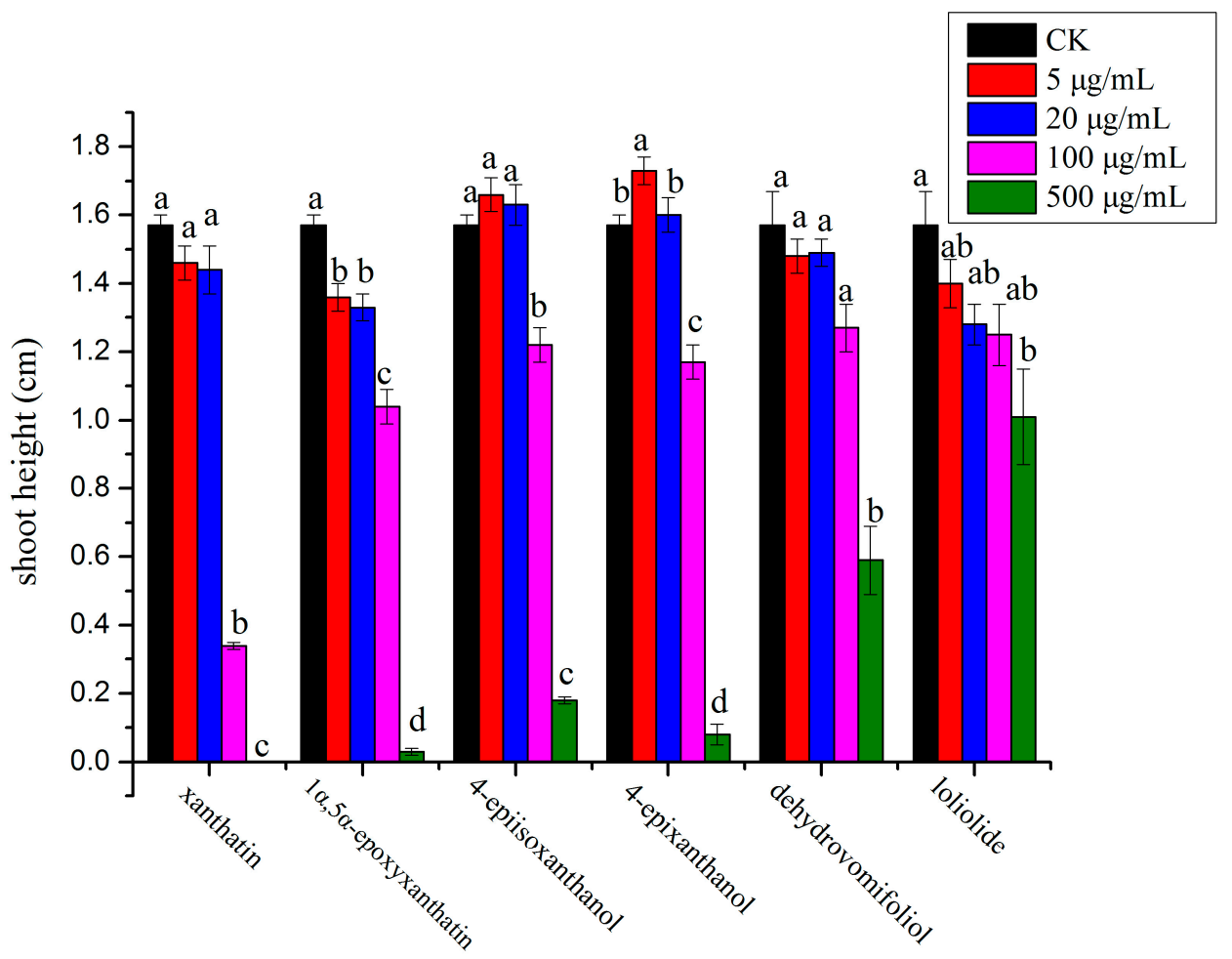

Figure 4. Phytotoxic effect of isolated compounds on shoot growth of A. retroflexus. Different letters represent a significant difference at $p<0.05$ level according to Fisher's LSD test.

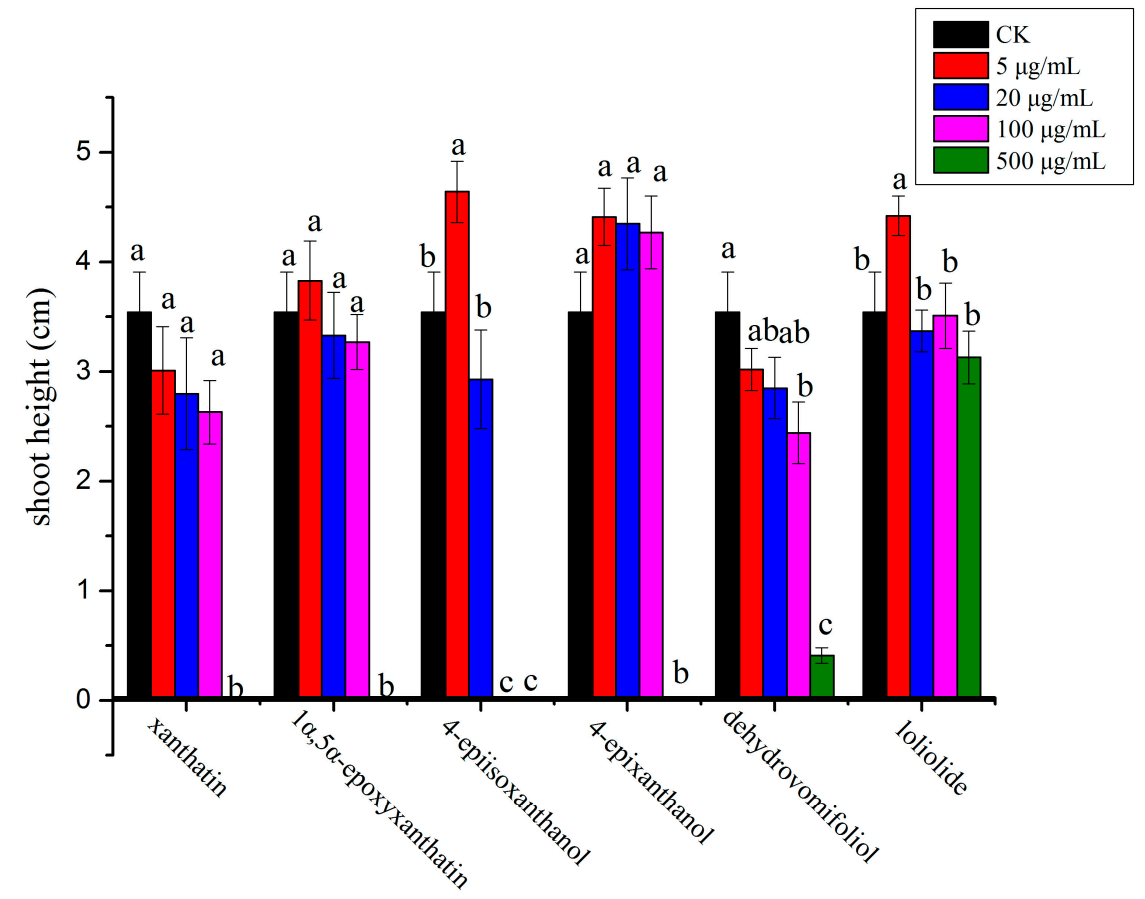

Figure 5. Phytotoxic effect of isolated compounds on shoot growth of P. annua. Different letters represent a significant difference at $p<0.05$ level according to Fisher's LSD test.

\section{Discussion}

Xanthium plants have been used in folk medicine for treating sinusitis, cancers, fever, diabetes, and heart troubles [26-28]. In particular, X. spinosum was applied against rabies, to relieve chronic fevers, to abate diabetes effect, and even to stimulate saliva production $[29,30]$. The chemistry of 
this genus is quite homogeneous: sesquiterpene lactones with guaiane or guaiane frameworks (i.e., xanthanolides) are the main secondary metabolites of most Xanthium species [12]. So far, a variety of xanthanolides have been isolated from Xanthium plants such as X. italicum, X. brasilicum, X. catharticum, X. cavanillesii, X. macrocarpum, X. orientale, and so on [12]. Sesquiterpenoid lactones are known for their biological/pharmacological activities. Frequently isolated sesquiterpene lactones such as xanthatin, xanthinol, xanthinosin, xanthinin, etc., have been reported to possess antimicrobial, anti-tumor, anti-leishmanial, anti-ulcerogen, anti-inflammatory, and plant growth regulatory activities [12,22,31-34]. Among the various biological activities, some xanthanolides such as xanthinin, xanthinosin, xanthatin, and 8-epi-xanthatin have been reported to possess plant growth inhibitory activity; xanthatin seems to be the most potent compound, reducing root growth of ryegrass and Syrian rue by $78 \%$ and $96 \%$, respectively, at $50 \mu \mathrm{g} / \mathrm{mL}$; xanthinin showed weaker activity, $250 \mu \mathrm{g} / \mathrm{mL}$ xanthinin inhibited root growth of lettuce, ryegrass, Syrian rue and redroot pigweed by $33 \%$, and $66 \%, 94 \%, 3 \%$, and $99.7 \%$, respectively; as of 8 -epi-xanthatin, it was found to be able to inhibit auxin-induced growth of sunflower hypocotyl and oat coleoptile sections at concentrations higher than $100 \mathrm{mM}$ and $30 \mathrm{mM}$, respectively, and the elongation of cress roots at concentrations higher than $30 \mathrm{mM}[9,35-37]$.

Unlike the isolated xanthanolides, compounds 5 and $\mathbf{6}$ are not limited to Xanthium plants and can be found in other species. Both compounds have previously been reported to possess phytotoxic activity [38]. Compound 5 has been isolated from Marsilea crenata, Bunias orientalis, Centrostachys aquatic, etc., and can be found in lots of marine algae with the content ranging from $0.14 \sim 4.83 \mu \mathrm{g} / \mathrm{g}$; and the concentrations required for $50 \%$ inhibition of cress and barnyard grass seedlings by loliolide ranged from 32.1 to $128.5 \mathrm{mM}$ [39-41]. Compound 6 have also been obtained as a phytotoxic substance from Raphanussativus, Chenopodium album, and Malva silvestris [42-44]; Interestingly, compounds 5 and 6 have been isolated together as the 2 major allelopathic substances from the herbaceous perennial weed Paspalum commersonii [38]. Although the phytotoxicity of compounds 5 and $\mathbf{6}$ was too weak to be considered as valuable candidates to be further exploited as bioherbicides, the 4 xanthanolides exhibited relatively strong activity, especially compound $\mathbf{1}$.

Synthetic herbicides are widely used in weed management, however they are criticized due to their possible involvement of causing serious irreversible environmental problems. Natural herbicides, on the contrary, can be degraded by soil microbes and are thus considered to be environmentally friendly [45]. A number of naturally occurring compounds have been found to possess potent plant inhibitory activity, such as DIMBOA, citral, aspterric acid, cinnacidin, etc., and some of them (or their derivatives/analogues) have been successfully commercialized [46-49]. For example, mesotrione is a synthesized analogue of leptospermone, which was originally discovered from roots of Callistemon citrinus [50]; another herbicide cinmethylin is actually a derivative of 1,4-cineole, which can be found as an important constituent of the essential oils of a number of plants such as Eucalyptus citriodora [51,52]; and Endothall is an analogue of the natural compound cantharidin [53]. To the best of our knowledge, this is the first report on the phytotoxicity of 3 xanthanolides, i.e., compounds $2-4$ and their effective influence on seedling growth of receiver plants implies their potential to be utilized as bioherbicides.

Besides X. spinosum, other Xanthium species have also been reported as invasive plants, such as X. italicum, X. strumarium, X. mongolicum, etc., most likely due to their unique biological characteristics [16]. In the case of X. spinosum, our results revealed that X. spinosum has the ability to produce phytotoxic substances. It is proposed that some exotic plants can affect local ecosystems via allelopathy, by either directly release toxic substances (allelochemicals) into the environment, or indirectly impact aboveground ecosystems by shifting soil physico-chemical properties as well as soil microbial communities [20,54]. Our previous study confirmed the presence of several xanthanolides, i.e., xanthinin, xanthatin, and xanthinosin, with moderate to strong phytotoxicity, in soils infested by another invasive Xanthium plant, i.e., X. italicum, suggesting these xanthanolides might contribute, at least in part, to the allelopathic property of this plant. However, further work is needed to determine 
the role of these bioactive compounds in the invasion process of X. spinosum, for instance, whether these potential allelochemicals can persist in soil long enough to act as inhibitory agents.

\section{Conclusions}

Six compounds with phytotoxic activities were isolated from the invasive plant X. spinosum, and this is the first report of the phytoxicity of compounds $2-4$. The compound 3 exhibited significant selective activity between the monocot and dicot receiver species, implying its possible use as a natural selective herbicide. Our work indicated the possible mechanism of X. spinosum producing substances with allelopathic potential to suppress growth of native species and to facilitate its invasion success.

\section{Materials and Methods}

\subsection{Plant Material}

Aerial parts of X. spinosum were collected in Yining city, Xinjiang province in July 2015. Leaves were separated from the stems and air dried in our laboratory at room temperature for 2 weeks. They were then powdered by an electric grinder for further process.

\subsection{Extraction and Isolation}

Ground leaves of X. spinosum $(8.6 \mathrm{~kg})$ was macerated in $95 \%$ ethanol $(8 \mathrm{~L})$ for a week and the plant material was filtered off; the same process was repeated three times. The filtrates were combined and evaporated to yield a residue $(90 \mathrm{~g})$ that was fractionated with different solvents on the basis of increasing polarity to afford petroleum ether fraction (72.6 g), ethyl acetate fraction $(10 \mathrm{~g})$, and the residue $(9.4 \mathrm{~g})$. The ethyl acetate fraction exhibited the strongest phytotoxic activity; therefore it was subjected to column chromatography over a silica gel column eluted with a step gradient elution (PET/EtOAc at 1:0, 5:1, 3:1, 1:1, 1:2, 0:1, and EtOAc/MeOH at 98:2, 96:4, 9:1, 8:2, 0:1). Seventeen fractions were collected based on TLC profiles, and their phytotoxicity was determined at $500 \mu \mathrm{g} / \mathrm{mL}$ against $A$. retroflexus. The most toxic fractions, fractions 4,5 and 7 , were selected for further purification. Fraction 4 was recrystallized in methanol to yield compound 1 (20.3 mg). Fraction 5 was subjected to HPLC with a Phenomenex C18 Column $(10 \mu \mathrm{m}, 250 \times 10 \mathrm{~mm})$ and methanol/water (3:7-7:3) as the eluent at a flow rate of $3 \mathrm{~mL} / \mathrm{min}$. This process afforded the following products: compound $2(12.7 \mathrm{mg})$, compound $3(36.9 \mathrm{mg})$, compound $5(4.0 \mathrm{mg})$ and compound 6 $(4.7 \mathrm{mg})$. Fraction 7 was chromatographed by HPLC with a Phenomenex C18 Column $(10 \mu \mathrm{m}$, $250 \times 10 \mathrm{~mm})$ and methanol/water $(3: 7-7: 3)$ as the at a flow rate of $3 \mathrm{~mL} / \mathrm{min}$ to give compound 4 (5.1 mg). To determine the chemical structures of the purified compounds with phytotoxic activity, their spectral data were measured as under: ${ }^{1} \mathrm{H}$ and ${ }^{13} \mathrm{C}$ NMR spectra were recorded on a Varian Inova-400 instrument (Varian, Boulder, $\mathrm{CO}$, USA) with TMS as an internal standard and $\mathrm{CD}_{3} \mathrm{OD}$ as solvent, and EIMS was performed using a 4000 QTRAP Elite LC-MS/MS system from Applied Biosystems/MDS Sciex (Concord, ON, Canada) coupled with an electrospray ionisation (ESI).

\subsection{Compounds Characterization}

Compound 1: was obtained as a pale yellowish oil, and its molecular formula was deduced to be $\mathrm{C}_{15} \mathrm{H}_{18} \mathrm{O}_{3}$ from the ESI-MS $\left(\mathrm{m} / z 247.7[\mathrm{M}+\mathrm{H}]^{+}\right)$, as was consistent with mass spectral data of xanthatin reported in the literature (see Figure S3) [22]; ${ }^{1} \mathrm{H} \mathrm{NMR}\left(400 \mathrm{MHz}, \mathrm{CDCl}_{3}, \delta \mathrm{ppm}\right): 2.29(\mathrm{~s}, 3 \mathrm{H}$, $\left.15-\mathrm{CH}_{3}\right), 1.14\left(d, 3 \mathrm{H}, J=8.0 \mathrm{~Hz}, 14-\mathrm{CH}_{3}\right), 7.06(d, 1 \mathrm{H}, J=16.0 \mathrm{~Hz}, 2-\mathrm{H}), 6.27(d d, 1 \mathrm{H}, J=4.0,8.0 \mathrm{~Hz}, 5-\mathrm{H})$, $6.20(d, 1 \mathrm{H}, J=16.0,3-\mathrm{H}), 6.19(d, 1 \mathrm{H}, J=4.0,13-\mathrm{H}), 5.47\left(d, 1 \mathrm{H}, J=4.0,13^{\prime}-\mathrm{H}\right), 4.27(t, 1 \mathrm{H}, J=12.0,8-\mathrm{H})$, $3.05(m, 1 \mathrm{H}, 7-\mathrm{H}), 2.79(m, 1 \mathrm{H}, 6 \beta-\mathrm{H}), 2.55(m, 1 \mathrm{H}, 10-\mathrm{H}), 2.38(t d, 1 \mathrm{H}, J=4.0,12.0 \mathrm{~Hz}, 9 \beta-\mathrm{H}), 2.22(t d$, $1 \mathrm{H}, J=4.0,12.0 \mathrm{~Hz}, 9 \alpha-\mathrm{H}), 1.84(t d, J=4.0,16.0 \mathrm{~Hz}, 1 \mathrm{H}, 6 \alpha-\mathrm{H}) ;{ }^{13} \mathrm{C} \mathrm{NMR}\left(100 \mathrm{MHz}, \mathrm{CDCl}_{3}, \delta \mathrm{ppm}\right)$ : 18.83 (14-C), 27.21 (6-C), 27.88 (15-C), 29.16 (10-C), 36.60 (9-C), 47.46 (7-C), 81.47 (8-C), 118.91 (13-C), 124.67 (3-C), 137.97 (5-C), 139.22 (11-C), 144.78 (1-C), 148.44 (2-C), 169.62 (12-C), 198.43 (4-C). They were 
also identical to the data of xanthatin reported in the literature [22]. From these spectral data, the structure of $\mathbf{1}$ was elucidated as xanthatin.

Compound 2: was obtained as a pale yellowish oil, and its molecular formula was deduced to be $\mathrm{C}_{15} \mathrm{H}_{18} \mathrm{O}_{4}$ from the ESI-MS $\left(m / z 263.8[\mathrm{M}+\mathrm{H}]^{+}\right)$, as was consistent with mass spectral data of $1 \alpha, 5 \alpha$-epoxyxanthatin reported in the literature [23]; ${ }^{1} \mathrm{H}$ NMR $\left(400 \mathrm{MHz}, \mathrm{CDCl}_{3}, \delta \mathrm{ppm}\right): 2.24(s, 3 \mathrm{H}$, $\left.15-\mathrm{CH}_{3}\right), 1.27\left(d, 3 \mathrm{H}, J=8.0 \mathrm{~Hz}, 14-\mathrm{CH}_{3}\right), 6.90(d, 1 \mathrm{H}, J=16.0 \mathrm{~Hz}, 2-\mathrm{H}), 6.28(d, 1 \mathrm{H}, J=16.0,3-\mathrm{H})$, $6.15(d, 1 \mathrm{H}, J=4.0,13-\mathrm{H}), 5.44\left(d, 1 \mathrm{H}, J=4.0,13^{\prime}-\mathrm{H}\right), 3.91(t d, 1 \mathrm{H}, J=4.0,12.0,8-\mathrm{H}), 3.05(d, 1 \mathrm{H}, J=4.0$, 5-H), $2.88(m, 1 \mathrm{H}, 7-\mathrm{H}), 2.65(m, 1 \mathrm{H}, 6 \beta-\mathrm{H}), 2.59(m, 1 \mathrm{H}, 10-\mathrm{H}), 2.11(d t, 1 \mathrm{H}, J=4.0,12.0 \mathrm{~Hz}, 9 \beta-\mathrm{H})$, $2.0(d t, 1 \mathrm{H}, J=4.0,12.0 \mathrm{~Hz}, 9 \alpha-\mathrm{H}), 1.90(d, J=4.0,1 \mathrm{H}, 6 \alpha-\mathrm{H}) ;{ }^{13} \mathrm{C} \mathrm{NMR}\left(100 \mathrm{MHz}, \mathrm{CDCl}_{3}, \delta \mathrm{ppm}\right):$ 16.34 (14-C), 26.27 (15-C), 28.22 (9-C), 30.47 (6-C), 34.41 (10-C), 42.85 (7-C), 63.59 (5-C), 64.93 (1-C), $80.14(8-C), 118.53$ (13-C), 129.03 (3-C), 139.43 (11-C), 145.03 (2-C), 169.37 (12-C), 197.90 (4-C). They were also identical to the data of $1 \alpha, 5 \alpha$-epoxyxanthatin reported in the literature [23]. From these spectral data, the structure of 2 was elucidated as $1 \alpha, 5 \alpha$-epoxyxanthatin.

Compound 3: was obtained as a yellowish oil, and its molecular formula was deduced to be $\mathrm{C}_{17} \mathrm{H}_{24} \mathrm{O}_{5}$ from the ESI-MS $\left(m / z 307.4[\mathrm{M}-\mathrm{H}]^{-}\right)$, as was consistent with mass spectral data of 4-epiisoxanthanol reported in the literature [22]; ${ }^{1} \mathrm{H}$ NMR $\left(400 \mathrm{MHz}, \mathrm{CD}_{3} \mathrm{OD}, \delta \mathrm{ppm}\right): 2.01\left(d, 3 \mathrm{H}, J=4.0 \mathrm{~Hz}, \mathrm{OAC}-\mathrm{CH}_{3}\right)$, $1.21\left(d, 3 \mathrm{H}, J=8.0 \mathrm{~Hz}, 15-\mathrm{CH}_{3}\right), 1.19\left(d, 3 \mathrm{H}, J=8.0 \mathrm{~Hz}, 14-\mathrm{CH}_{3}\right), 6.07(d, 1 \mathrm{H}, J=4.0,13-\mathrm{H}), 5.71(b r, d d$, $1 \mathrm{H}, J=4.0,12.0,5-\mathrm{H}), 5.54\left(d, 1 \mathrm{H}, J=4.0,13^{\prime}-\mathrm{H}\right), 4.37(t d, 1 \mathrm{H}, J=4.0,12.0,4-\mathrm{H}), 4.08(t, 1 \mathrm{H}, J=8.0,8-\mathrm{H})$, $3.29(t, 1 \mathrm{H}, J=4.0,2-\mathrm{H}), 2.79(m, 1 \mathrm{H}, 10-\mathrm{H}), 2.54(d d d, 1 \mathrm{H}, J=4.0,8.0 \mathrm{~Hz}, 6 \alpha-\mathrm{H}), 2.47(d d d, 1 \mathrm{H}, J=4.0$, $8.0 \mathrm{~Hz}, 7-\mathrm{H}), 2.28(d d d, 1 \mathrm{H}, J=4.0,8.0 \mathrm{~Hz}, 9 \beta-\mathrm{H}), 2.12(d d d, 1 \mathrm{H}, J=4.0,8.0 \mathrm{~Hz}, 6 \beta-\mathrm{H}), 1.91(m, 1 \mathrm{H}, 9 \alpha-\mathrm{H})$,

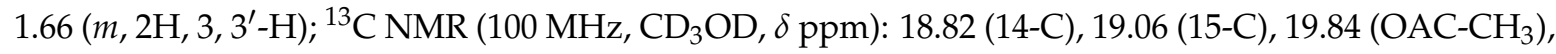
$24.71(6-C), 28.52$ (10-C), 36.49 (9-C), 40.54 (3-C), 48.25 (7-C), 68.70 (4-C), 75.80 (2-C), 82.77 (8-C), 117.58 (13-C), 124.50 (5-C), 140.00 (11-C), 148.75 (1-C), 170.63 (12-C), 171.04 (OAC-C). They were also identical to the data of 4-epiisoxanthanol reported in the literature [22]. From these spectral data, the structure of $\mathbf{3}$ was elucidated as 4-epiisoxanthanol.

Compound 4: was obtained as a yellowish oil, and its molecular formula was deduced to be $\mathrm{C}_{17} \mathrm{H}_{24} \mathrm{O}_{5}$ from the ESI-MS $\left(m / z 307.4[\mathrm{M}-\mathrm{H}]^{-}\right)$, as was consistent with mass spectral data of 4-epixanthanol

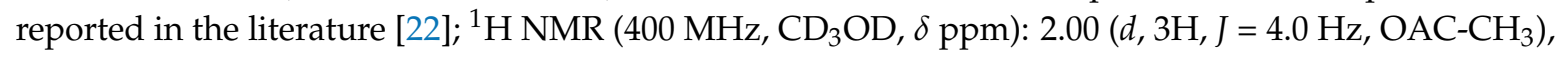
$1.21\left(t, 3 \mathrm{H}, J=8.0 \mathrm{~Hz}, 15-\mathrm{CH}_{3}\right), 1.14\left(d, 3 \mathrm{H}, J=8.0 \mathrm{~Hz}, 14-\mathrm{CH}_{3}\right), 6.07(d, 1 \mathrm{H}, J=4.0,13-\mathrm{H}), 5.97(d d$, $1 \mathrm{H}, J=4.0,12.0,5-\mathrm{H}), 5.54\left(d, 1 \mathrm{H}, J=4.0,13^{\prime}-\mathrm{H}\right), 5.32(t, 1 \mathrm{H}, J=8.0,2-\mathrm{H}), 4.37(t d, 1 \mathrm{H}, J=4.0,12.0$, 8-H), $3.69(m, 1 \mathrm{H}, 4-\mathrm{H}), 2.79(m, 1 \mathrm{H}, 10-\mathrm{H}), 2.62(d d d, 1 \mathrm{H}, J=4.0,8.0 \mathrm{~Hz}, 6 \alpha-\mathrm{H}), 2.47(d d d, 1 \mathrm{H}, J=4.0$, $8.0 \mathrm{~Hz}, 7-\mathrm{H}), 2.28(d d d, 1 \mathrm{H}, J=4.0,8.0 \mathrm{~Hz}, 9 \beta-\mathrm{H}), 2.14(d d d, 1 \mathrm{H}, J=4.0,8.0 \mathrm{~Hz}, 6 \beta-\mathrm{H}), 1.89(m, 1 \mathrm{H}$,

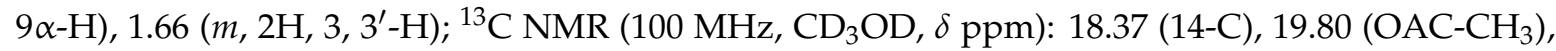
22.38 (15-C), 24.64 (6-C), 29.11 (10-C), 36.54 (9-C), 41.54 (3-C), 48.10 (7-C), 64.13 (4-C), 78.76 (2-C), 82.49 (8-C), 117.59 (13-C), 127.45 (5-C), 139.85 (11-C), 144.75 (1-C), 170.50 (12-C), 171.06 (OAC-C). They were also identical to the data of 4-epixanthanol reported in the literature [22]. From these spectral data, the structure of 4 was elucidated as 4-epixanthanol.

Compound 5: was obtained as a colorless crystal, and its molecular formula was deduced to be $\mathrm{C}_{11} \mathrm{H}_{16} \mathrm{O}_{3}$ from the ESI-MS $\left(\mathrm{m} / z 197.5[\mathrm{M}+\mathrm{H}]^{+}\right)$, as was consistent with mass spectral data of loliolide reported in the literature [24]; ${ }^{1} \mathrm{H}$ NMR $\left(400 \mathrm{MHz}, \mathrm{CD}_{3} \mathrm{OD}, \delta \mathrm{ppm}\right): 1.74\left(s, 3 \mathrm{H}, 11-\mathrm{CH}_{3}\right), 1.45(s, 3 \mathrm{H}$, 9- $\left.\mathrm{CH}_{3}\right), 1.26\left(\mathrm{~s}, 3 \mathrm{H}, 10-\mathrm{CH}_{3}\right), 4.19(\mathrm{~s}, 1 \mathrm{H}, 3-\mathrm{H}), 2.46(d t, 1 \mathrm{H}, J=4.0,16.0,4 \beta-\mathrm{H}), 1.98(d t, 1 \mathrm{H}, J=4.0,16.0$, $2 \beta-\mathrm{H}), 1.71(d, 1 \mathrm{H}, J=4.0,4 \alpha-\mathrm{H}), 1.50(d d d, 1 \mathrm{H}, J=4.0,8.0 \mathrm{~Hz}, 2 \alpha-\mathrm{H}) ;{ }^{13} \mathrm{C}$ NMR $\left(100 \mathrm{MHz}, \mathrm{CD}_{3} \mathrm{OD}, \delta\right.$ ppm): $25.52\left(9-\mathrm{CH}_{3}\right), 25.99\left(11-\mathrm{CH}_{3}\right), 29.57\left(10-\mathrm{CH}_{3}\right), 35.75$ (1-C), 44.99 (4-C), 46.53 (2-C), 65.80 (3-C), 87.52 (5-C), 111.88 (7-C), $172.12(6-\mathrm{C}), 184.13$ (8-C). They were also identical to the data of loliolide reported in the literature [25]. From these spectral data, the structure of 5 was elucidated as loliolide.

Compound 6: was obtained as a white crystal, and its molecular formula was deduced to be $\mathrm{C}_{13} \mathrm{H}_{18} \mathrm{O}_{3}$ from the ESI-MS $\left(m / z 221.3[\mathrm{M}-\mathrm{H}]^{+}\right)$, as was consistent with mass spectral data of dehydrovomifoliol reported in the literature [25]; ${ }^{1} \mathrm{H}$ NMR $\left(400 \mathrm{MHz}, \mathrm{CD}_{3} \mathrm{OD}, \delta \mathrm{ppm}\right): 2.29\left(s, 3 \mathrm{H}, 10-\mathrm{CH}_{3}\right), 1.87(d, 3 \mathrm{H}$, 
$\left.J=8.0 \mathrm{~Hz}, 11-\mathrm{CH}_{3}\right), 1.05\left(\mathrm{~s}, 3 \mathrm{H}, 13-\mathrm{CH}_{3}\right), 1.00\left(\mathrm{~s}, 3 \mathrm{H}, 12-\mathrm{CH}_{3}\right), 6.98(d, 1 \mathrm{H}, J=16.0,7-\mathrm{H}), 6.42(d, 1 \mathrm{H}$, $J=16.0,8-\mathrm{H}), 5.92(s, 1 \mathrm{H}, 4-\mathrm{H}), 2.56(s, 1 \mathrm{H}, 2 \alpha-\mathrm{H}), 2.24(s, 1 \mathrm{H}, 2 \beta-\mathrm{H}) ;{ }^{13} \mathrm{C}$ NMR $\left(100 \mathrm{MHz}, \mathrm{CD}_{3} \mathrm{OD}\right.$, $\delta$ ppm): $17.71(11-\mathrm{C}), 22.07\left(12-\mathrm{CH}_{3}\right), 23.30\left(13-\mathrm{CH}_{3}\right), 26.19\left(10-\mathrm{CH}_{3}\right), 41.21$ (1-C), 49.08 (2-C), 78.59 (6-C), 126.59 (4-C), 130.27 (8-C), 146.90 (7-C), 163.20 (5-C), 198.92 (3-C), 199.21 (9-C). They were also identical to the data of dehydrovomifoliol reported in the literature [25]. From these spectral data, the structure of 6 was elucidated as dehydrovomifoliol.

\subsection{Phytotoxicity Bioassays}

A dicot plant, Amaranthus retroflexus L., and a monocot plant, Poa annua L., were used as receiver plants for testing the phytotoxic activity of the isolated compounds. Seeds of A. retroflexus and P. annua were surface sterilized with $0.5 \% \mathrm{HgCl}_{2}$ before use. Isolated compounds were dissolved in methanol to give solutions at $5,20,100,500 \mu \mathrm{g} / \mathrm{mL}$ and added to petri dishes ( $3 \mathrm{~cm}$ diameter) lined with filter papers. After complete evaporation of methanol, distilled water $(1 \mathrm{~mL})$ was added to each petri dish followed by addition of 10 seeds. All petri dishes were stored in the dark at $25^{\circ} \mathrm{C}$. Seedlings were allowed to grow for 6 (for A. retroflexus) or 8 (for P. annua) days before shoot and root length were measured. Three replicates were made for each treatment $(\mathrm{N}=30)$.

\subsection{Statistical Analyses}

The significance of the phytotoxic activity of compounds 1-6 on seedling growth of receiver species was first examined by ANOVA $(p<0.05)$ and then analyzed using Fisher's LSD (Least Significant Difference) test at $p<0.05$ level. All statistical analyses were performed with SPSS 13 .

Supplementary Materials: The following are available online. Figure S1: ${ }^{1} \mathrm{H}$ NMR spectrum of xanthatin (1) $\left(\mathrm{CDCl}_{3}, 400 \mathrm{MHz}\right)$, Figure $\mathrm{S} 2:{ }^{13} \mathrm{C}$ NMR spectrum of xanthatin $(\mathbf{1})\left(\mathrm{CDCl}_{3}, 100 \mathrm{MHz}\right)$, Figure $\mathrm{S} 3$ : Mass spectrum of xanthatin (1), Figure S4: ${ }^{1} \mathrm{H}$ NMR spectrum of $1 \alpha, 5 \alpha$-epoxyxanthatin (2) $\left(\mathrm{CDCl}_{3}, 400 \mathrm{MHz}\right)$, Figure S5: ${ }^{13} \mathrm{C}$ NMR spectrum of $1 \alpha, 5 \alpha$-epoxyxanthatin (2) $\left(\mathrm{CDCl}_{3}, 100 \mathrm{MHz}\right)$, Figure S6: Mass spectrum of $1 \alpha, 5 \alpha$-epoxyxanthatin (2), Figure S7: ${ }^{1} \mathrm{H}$ NMR spectrum of 4-epiisoxanthanol (3) $\left(\mathrm{CD}_{3} \mathrm{OD}, 400 \mathrm{MHz}\right)$, Figure S8: ${ }^{13} \mathrm{C}$ NMR spectrum of 4-epiisoxanthanol (3) $\left(\mathrm{CD}_{3} \mathrm{OD}, 100 \mathrm{MHz}\right)$, Figure S9: Mass spectrum of 4-epiisoxanthanol (3), Figure S10: ${ }^{1} \mathrm{H} N \mathrm{NR}$ spectrum of 4-epiisoxanthanol (4) $\left(\mathrm{CD}_{3} \mathrm{OD}, 400 \mathrm{MHz}\right)$, Figure S11: ${ }^{13} \mathrm{C}$ NMR spectrum of 4-epiisoxanthanol (4) $\left(\mathrm{CD}_{3} \mathrm{OD}, 100 \mathrm{MHz}\right)$, Figure S12: Mass spectrum of 4-epiisoxanthanol (4), Figure S13: ${ }^{1} \mathrm{H}$ NMR spectrum of loliolide (5) $\left(\mathrm{CD}_{3} \mathrm{OD}, 400 \mathrm{MHz}\right)$, Figure $\mathrm{S} 14:{ }^{13} \mathrm{C}$ NMR spectrum of loliolide $(5)\left(\mathrm{CD}_{3} \mathrm{OD}, 100 \mathrm{MHz}\right)$, Figure S15: Mass spectrum of loliolide (5), Figure S16: ${ }^{1} \mathrm{H}$ NMR spectrum of dehydrovomifoliol (6) $\left(\mathrm{CD}_{3} \mathrm{OD}, 400 \mathrm{MHz}\right)$, Figure S17: ${ }^{13} \mathrm{C}$ NMR spectrum of dehydrovomifoliol (6) $\left(\mathrm{CD}_{3} \mathrm{OD}, 100 \mathrm{MHz}\right)$, Figure S18: Mass spectrum of dehydrovomifoliol (6).

Author Contributions: Conceptualization, Y.H. and X.Z.; Methodology, X.Z. and Y.H.; Validation, Z.Y. and Y.H.; Formal Analysis, S.Z.; Investigation, Z.Y, S.Z. and C.W.; Resources, C.W.; Data Curation, X.Z. and S.Z.; Writing-Original Draft Preparation, Z.Y.; Writing-Review \& Editing, X.Z., Z.Y. and H.S.; Visualization, H.S.; Supervision, Y.H.; Project Administration, X.Z. and Y.H.; Funding Acquisition, Y.H. and H.S.

Funding: This research was funded by the National Natural Science Foundation of China $(31460164,31660144$, 31770586).

Conflicts of Interest: The authors declare no conflict of interest.

\section{References}

1. Yurkonis, K.A.; Meiners, S.J.; Wachholder, B.E. Invasion impacts diversity through altered community dynamics. J. Ecol. 2005, 93, 1053-1061. [CrossRef]

2. Keane, R.M.; Crawley, M.J. Exotic plant invasions and the enemy release hypothesis. Trends Ecol. Evol. 2002, 17, 164-170. [CrossRef]

3. Marler, M.J.; Zabinski, C.A.; Callaway, R.M. Mycorrhizae indirectly enhance competitive effects of an invasive forb on a native bunchgrass. Ecology 1999, 80, 1180-1186. [CrossRef]

4. Callaway, R.M.; Aschehoug, E.T. Invasive plants versus their new and old neighbors: A mechanism for exotic invasion. Science 2000, 290, 521-523. [CrossRef] [PubMed] 
5. Callaway, R.M.; Ridenour, W.M. Novel weapons: Invasive success and the evolution of increased competitive ability. Front. Ecol. Environ. 2004, 2, 436-443. [CrossRef]

6. Thorpe, A.S.; Thelen, G.C.; Diaconu, A.; Callaway, R.M. Root exudate is allelopathic in invaded community but not in native community: Field evidence for the novel weapons hypothesis. J. Ecol. 2009, 97, 641-645. [CrossRef]

7. Rice, E.L. Allelopathy, 2nd ed.; Academic Press: New York, NY, USA, 1984; p. 422.

8. Gibson, D.M.; Krasnoff, S.B.; Biazzo, J.; Milbrath, L. Phytotoxicity of antofine from invasive swallow-worts. J. Chem. Ecol. 2011, 37, 871-879. [CrossRef] [PubMed]

9. Shao, H.; Zeng, R.S.; Wang, R.L.; Zhang, B.C.; Zhang, C. Selective phytotoxicity of xanthinin and xanthatin from invasive weed Xanthium italicum Morretti on test plants. Allelopathy J. 2015, 35, 77-86.

10. Blair, A.C.; Nissen, S.J.; Brunk, G.R.; Hufbauer, R.A. A lack of evidence for an ecological role of the putative allelochemical (+/-)-catechin in spotted knapweed invasion success. J. Chem. Ecol. 2006, 32, 2327-2331. [CrossRef] [PubMed]

11. Duke, S.O.; Blair, A.C.; Dayan, F.E.; Johnson, R.D.; Meepagala, K.M.; Cook, D.; Bajsa, J. Is (-)-catechin a novel weapon of spotted knapweed (Centaurea stoebe)? J. Chem. Ecol. 2009, 35, 141-153. [CrossRef] [PubMed]

12. Vasas, A.; Hohmann, J. Xanthanesesquiterpenoids: Structure, synthesis and biological activity. Nat. Prod. Rep. 2011, 28, 824-842. [CrossRef] [PubMed]

13. Tutin, T.G.; Heywood, V.H.; Burges, N.A. Flora Eurpopaea, 4th ed.; Cambridge University Press: London, UK, 1976; p. 143.

14. Zhao, L.Q.; Zang, C.X.; Yang, J. Distribtion of a invasive species Xanthium spinosum L. in Inner Mongolia and Ningxia. Acta Sci. Nat. Univ. Neimongol 2006, 37, 308-310.

15. Ma, H.S.; Chen, X.L.; Wang, Y.B. One new record species of Xanthium from Gansu and its key to species. J. Anhui Agric. Sci. 2012, 40, 11-12.

16. Du, Z.Z.; Xu, W.B.; Yan, P.; Wang, S.S.; Guo, Y.M. Three newly recorded alien invasive plants of Xanthium in Xinjiang. Xinjiang Agric. Sci. 2012, 49, 879-886.

17. Wang, S.X.; Zhao, L.; Gao, G.Z.; Zhang, X.T.; Yuan, W.F.; Chen, J. Risk analysis of the invasive plant (Xanthium spinoum L.) in Anhui province. J. Anhui Agric. Sci. 2015, 43, 147-149.

18. Auld, B.A.; McRae, C.F.; Say, M.M. Possible control of Xanthium spinosum by a fungus. Agric. Ecosyst. Environ. 1988, 21, 219-223. [CrossRef]

19. Inderjit; van der Putten, W.H. Impacts of soil microbial communities on exotic plant invasions. Trends Ecol. Evol. 2010, 25, 512-519.

20. Weidenhamer, J.D.; Callaway, R.M. Direct and indirect effects of invasive plants on soil chemistry and ecosystem function. J. Chem. Ecol. 2010, 36, 59-69. [CrossRef] [PubMed]

21. Yuan, Z.G.; Liu, Y.; Shao, H.; Zhao, Y.; Hu, Y.X. Allelopathy of each part of invasive plant Xanthium spinosum L. J. Henan Agric. Sci. 2017, 46, 73-77.

22. Marco, J.A.; Sanz-Cervera, J.F.; Corral, J.; Carda, M.; Jakupovic, J. Xanthanolides from Xanthium: Absolute configuration of xanthanol, isoxanthanol and C-4 epimers. Phytochemistry 1993, 34, 1569-1576. [CrossRef]

23. Mahmoud, A.A. Xanthanolides and xanthane epoxide derivatives from Xanthium strumarium. Planta Med. 1998, 64, 724-727. [CrossRef] [PubMed]

24. Wang, R.B.; Deng, S.D.; Qu, J.; Yu, S.S. Chemical consitituents from fruits of Xanthium chinense mill. Nat. Prod. Res. Dev. 2017, 29, 787-790.

25. Luo, M.; Huang, X.Z.; Li, Y.H.; Chuan, Y.M.; Wang, W.; Xiao, J.; Ruan, R.S.; Yang, Z.; Tian, K. A study of the chemical consitituents from the aerial part of dolichosfalcataklein. J. Yunnan Univ. Natl. 2018, 1, 1-4.

26. Nikles, S.; Heuberger, H.; Hilsdorf, E.; Schmücker, R.; Seidenberger, R.; Bauer, R. Influence of processing on the content of toxic carboxyatractyloside and atractyloside and the microbiological status of Xanthium sibiricum fruits (cang'erzi). Planta Med. 2015, 81, 1213-1220. [PubMed]

27. Bui, V.B.; Liu, S.T.; Zhu, J.J.; Xiong, J.; Zhao, Y.; Yang, G.X.; Gang, X.; Hu, J.F. Sesquiterpene lactones from the aerial parts of Xanthium sibiricum and their cytotoxic effects on human cancer cell lines. Phytochem. Lett. 2012, 5, 685-689. [CrossRef]

28. Pandey, D.P.; Rather, M.A. Isolation and identification of phytochemicals from Xanthium strumarium. Int. J. Chem. Res. 2012, 4, 266-271.

29. Han, T.; Zhang, H.; Li, H.L.; Zhang, Q.Y.; Zheng, H.C.; Qin, L.P. Composition of supercritical fluid extracts of some Xanthium species from China. Chem. Nat. Compd. 2008, 44, 814-816. [CrossRef] 
30. Babakhodzhaev, A.; Kasymov, S.Z.; Sidyakin, G.P. Xanthatin from Xanthium spinosum. Chem. Nat. Compd. 1973, 9, 529. [CrossRef]

31. Irving, R.; Huang, Y.; Hickie, R.A.; Sutherland, R.G.; Barl, B. Xanthatin and xanthinosin from the burs of Xanthium strumarium L. as potential anticancer agents. Can. J. Physiol. Pharm. 2007, 85, 1160-1172.

32. Favier, L.S.; María, A.O.M.; Wendel, G.H.; Borkowski, E.J.; Giordano, O.S.; Pelzer, L.; Tonn, C.E. Anti-ulcerogenic activity of xanthanolidesesquiterpenes from Xanthium cavanillesii in rats. J. Ethnopharmacol. 2005, 100, 260-267. [CrossRef] [PubMed]

33. Kovacs, A.; Vasas, A.; Forgo, P.; Rethy, B.; Zupko, I.; Hohmann, J. Xanthanolides with antitumour activity from Xanthium italicum. Z. Naturforsch. C 2009, 64, 343-349. [CrossRef] [PubMed]

34. Tsankova, E.T.; Trendafilova, A.B. Xanthanolides of Xanthium italicum Moretti and their biological activity. Z. Naturforsch. C 1994, 49, 154-155. [CrossRef] [PubMed]

35. Geissman, T.A.; Deuel, P.; Bonde, E.K.; Addicott, F.A. Xanthinin: A plant growth-regulating compound from Xanthium pennsylvanicum. J. Am. Chem. Soc. 1954, 76, 685-687. [CrossRef]

36. Yokotani-Tomita, K.; Katol, J.; Yamadal, K.; Kosemura, S.; Yamamura, S.; Bruinsma, J.; Hasegawa, K. 8-Epixanthatin, a light-induced growth inhibitor, mediates the phototropic curvature in sunflower (Helianthus annuus) hypocotyls. Physiol. Plant 1991, 106, 326-330. [CrossRef]

37. Shao, H.; Huang, X.L.; Wei, X.Y.; Zhang, C. Phytotoxic effect and a phytotoxin from the invasive plant Xanthium italicum Moretti. Molecules 2012, 17, 4037-4046. [CrossRef] [PubMed]

38. Zaman, F.; Iwasaki, A.; Suenaga, K.; Katonoguchi, H. Two allelopathic substances from Paspalum commersonii lam. Acta Agric. Scand. Sect. B 2017, 68, 342-348. [CrossRef]

39. Islam, M.S.; Iwasaki, A.; Suenaga, K.; Kato-Noguchi, H. Isolation and identification of two potential phytotoxic substances from the aquatic fern Marsilea crenata. J. Plant Biol. 2017, 60, 75-81. [CrossRef]

40. Bich, T.T.N.; Kato-Noguchi, H. Isolation and identification of a phytotoxic substance from the emergent macrophyte Centrostachys aquatica. Bot. Stud. 2014, 55, 1-5. [CrossRef] [PubMed]

41. Dietz, H.; Winterhalter, P. Phytotoxic constituents from Bunias orientalis leaves. Phytochemistry 1996, 42, 1005-1010. [CrossRef]

42. DellaGreca, M.; Marino, C.D.; Zarrelli, A.; D'Abrosca, B. Isolation and phytotoxicity of apocarotenoids from chenopodium album. J. Nat. Prod. 2004, 67, 1492. [CrossRef] [PubMed]

43. Fiorucci, L.; Mantovanelli, G.C.; Bernardi, D.I.; Silva, A.A.; de Oliveira, R.S., Jr.; Ishii-Iwamoto, E.L.; Sarragiotto, M.H.; Baldoqui, D.C. Isolation of the constituents and evaluation of allelopathic potential of Raphanus sativus L. (Brassicaceae). Planta Med. 2014, 80. [CrossRef]

44. Cutillo, F.; D'Abrosca, B.; Dellagreca, M.; Fiorentino, A.; Zarrelli, A. Terpenoids and phenol derivatives from malvasilvestris. Phytochemistry 2006, 67, 481-485. [CrossRef] [PubMed]

45. Duke, S.O.; Dayan, F.E.; Romangni, J.G.; Rimando, A.M. Natural products as sources of herbicides: Current status and future trends. Weed Res. 2000, 40, 99-111. [CrossRef]

46. Zheng, Y.Q.; Zhao, Y.; Dong, F.S.; Liu, X.G.; Yao, J.R.; Hurle, K. Allelopathic effects of wheat extracts and DIMBOA on weeds. Allelopathy J. 2007, 19, 171-178.

47. Elisa, G.; Tamara, S.; Reigosa, M.J. The phytotoxic potential of the terpenoidcitral on seedlings and adult plants. Weed Sci. 2001, 61, 469-481.

48. Yan, Y.; Liu, Q.K.; Zang, X.; Yuan, S.G.; Bat-Erdene, U.; Nguyen, C.; Gan, J.H.; Zhou, J.H.; Jacobsen, S.E.; Tang, Y. Resistance-gene-directed discovery of a natural-product herbicide with a new mode of action. Nature 2018, 559, 415-418. [CrossRef] [PubMed]

49. Irvine, N.M.; Yerkes, C.N.; Graupner, P.R.; Roberts, R.E.; Hahn, D.R.; Pearce, C. Synthesis and characterization of synthetic analogs of cinnacidin, a novel phytotoxin from Nectria sp. Pest. Manag. Sci. 2010, 64, 891-899. [CrossRef] [PubMed]

50. Mitchell, G.; Bartlett, D.W.; Fraser, T.E.; Hawkes, T.R.; Holt, D.C.; Townson, J.K.; Wichert, R.A. Mesotrione: A new selective herbicide for use in maize. Pest. Manag. Sci. 2001, 57, 120-128. [CrossRef]

51. Grayson, B.T.; Williams, K.S.; Freehauf, P.A.; Pease, R.R.; Ziesel, W.T.; Sereno, R.L.; Reinsfelder, R.E. The physical and chemical properties of the herbicide cinmethylin (SD 95481). Pestic. Sci. 2010, 21, $143-153$. [CrossRef]

52. Sultana, S.; Ali, M.; Ansari, S.H.; Bagri, P. The effect of physical factors on chemical composition of the essential oil of Eucalyptus citriodora hook. Leaves. J. Essent. Oil Bear Plants 2008, 11, 69-74. [CrossRef] 
53. Tresch, S.; Schmotz, J.; Grossmann, K. Probing mode of action in plant cell cycle by the herbicide endothall, a protein phosphatase inhibitor. Pestic. Biochem. Phys. 2011, 99, 86-95. [CrossRef]

54. Grove, S.; Haubensak, K.A.; Parker, I.M. Direct and indirect effects of allelopathy in the soil legacy of an exotic plant invasion. Plant. Ecol. 2012, 213, 869-1882. [CrossRef]

Sample Availability: Not available.

(C) 2018 by the authors. Licensee MDPI, Basel, Switzerland. This article is an open access article distributed under the terms and conditions of the Creative Commons Attribution (CC BY) license (http://creativecommons.org/licenses/by/4.0/). 